\title{
A Study Investigating the Perceived Service Quality Levels of Sport Center Members: A Kano Model Perspective
}

\author{
Kadir Yıldız ${ }^{1}$ Ercan Polat ${ }^{2}$, Pınar Güzel ${ }^{1}$ \\ ${ }^{1}$ Faculty of Sport Sciences, Manisa Celal Bayar University, Manisa, Turkey \\ ${ }^{2}$ School of Physical Education and Sport, Niğde Öner Halisdemir University, Niğde, Turkey \\ Correspondence: Kadir Yıldız, Faculty of Sport Sciences, Manisa Celal Bayar University, 45040, Manisa, Turkey.
}

Received: February 25, 2018

Accepted: March 4, $2018 \quad$ Online Published: March 18, 2018

doi:10.11114/jets.v6i4.3045

URL: https://doi.org/10.11114/jets.v6i4.3045

\begin{abstract}
The purpose of this study is to investigate sport center members' perceived service quality levels with a view to Kano customer expectations and requirements model. To that end, a descriptive approach and a correlational research design featuring survey method is adopted. Research group consists of 680 (300 women, 380 men) sport center members who are chosed through multistage sampling (Cluster). "Sport Fitness Centers Perceived Service Quality Scale and Expectation Scale are used as data collection tools. Independent samples t-test, Pearson Correlation analysis and Multiple Linear Regression tests are used to analyzed the data. In the light of the findings, it is seen that all the subdimensions have medium or high level positive significant relationships with the expectation when the subdimensions of the expectation scale and the SFC-PSQS are compared.

According to the results of the Independent Samples T-test, the expectation levels of the customers stating that the programme fee is expensive are significantly lower. In conclusion, as the customers' perception of service quality in the sport center increases, their expectation levels also generally increase significantly. The customers expect that the quality of service they receive to be high and to meet their expectations exceedingly. However, it is also predicted that physical and psychosocial factors affecting the expectation can also affect the perception of service quality at a significant level. Since the service quality and meeting the expectations of the customers is an important indicator to maintain the businesses' existence, studying with multiple factors attempting to understand the nature of service quality and the customer expectations should be conducted.
\end{abstract}

Keywords: sport center, service quality, expectation, Kano model

\section{Introduction}

The contemporary age is possibly best characterized by an outbreak of globalization and a growing competition across all fields of life. Sport industry has been inevitably influenced by those tides of change, innovation and development and has become a highly competitive sector. Sport organizations are forced to a fierce competition that threatens their survival, their prospects of higher revenues, increased customer engagement and their chances for recruiting new customers (Yerlisu Lapa \& Baştaç, 2012). To ensure the mentioned qualities, sport businesses need to make the high-quality presentation of services which is expected by the customers.

Expectation is defined as the anticipation and prediction of a future situation and especially as the possible benefit to be gained after meeting an already known need. In other words, expectation is seen as an important determiner of ensuring customer satisfaction and continuity in sport facilities and businesses (Yu et al., 2014). The concept of expectation is subjective, changeable, and event hard to identify most of the time. For this reason, thought needs and expectations sometimes emerge directly, some of them need to be discovered (Silvestro, 2002). In the light of the idea that customer expectations are to be handled in the social dimension, its variations should be analyzed in terms of its demographic, socio-economic, motivational and pragmatic factors. Because, in order for a sport centre to be successful, customer expectations are expected to be understood and met.

Conducting certain research towards identifying customer expectations in service industry possess a key function for businesses to maintain their existence (Parasuraman, Zeithaml \& Berry, 1985). Thus, in order to understand the topic of the satisfaction of customer expectations in businesses, how meeting these needs will affect the satisfaction levels should first 
be understood. With this purpose, Kano, Seraku, Takahashi \& Tsuji (1984) have developed a model to classify the service features to meet the customer needs (Figure 1). Rather than being purely theoretical, this model has importance in classifying the effects of customers' needs and expectations about a certain product or service on their satisfaction levels (Sofyalioğlu \& Tunail, 2012). Kano's quality theory is used to explore how various quality features affect customer satisfaction level and its role in the perception of a customer's quality perception (Högström, Rosner \& Gustafsson, 2010).

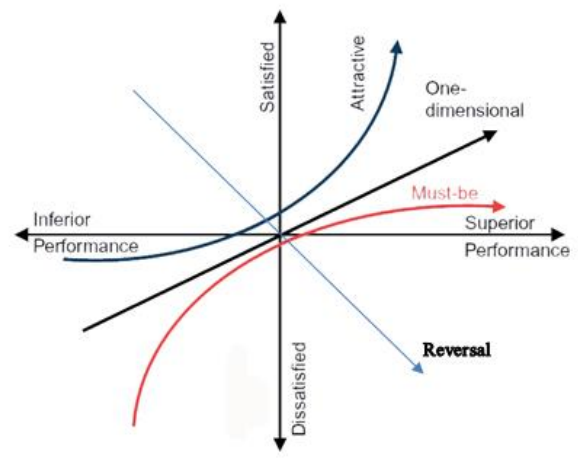

Figure 1. Kano Consumer Satisfaction Model (Chen \& Chuang, 2008)

According to the Kano model, not all the service types are equally important for the customers in a service provided. A requirement which is important for a customer can turn out to be equally unimportant for other customers. Important factors affecting this are the service content and the customer needs. There are five different service groups which cover the customer expectation and requirements. The first of these, must-be requirements are the product/service features the customers are not aware of most of the time, but their absence causes great dissatisfaction (Tontini \& Picolo, 2013).

Must be requirements are the types of services that the customers definitely expect in the related service (Chen \& Lin, 2007; Chien, 2007). For instance, in the absence of towels in a sport center, the customers will probably not be satisfied. However, it cannot be claimed that they will be satisfied in the presence of towels.

Sport centers which undergo a rapid growing process have to meet the requirements of the customers in order to satisfy them. Because, expectations may be under the influence of many factors including the communication with other customers, the personal needs of the customers, past experiences, the communication with the service providers, and the price-quality relationships (Howat, Absher, Crilley \& Milne, 1996). Service quality and expection factor can be considered as important factors for sport centers as well as all the other businesses. Because, the service provided by animate and inanimate beings cover many industries in a quite wide range such as tourism, education, health and sport (Y1ldı, 2009). Another group of service is the one-dimensional requirements which are demanded clearly by the customers. It is argued that there is a positive correlation between the level of meeting these requirements in businesses and the customer satisfaction (Kuo, 2004; Dixon \& Warner, 2010). These services are expressed as the services that the customers generally expect to benefit from (Giritlioğlu \& Korkmaz, 2014). For a sport center, the cleanness of the centers they enroll, the existence of basic tools and equipments, and smiling staff are among the expected service qualities that the customers expect. Within the service industry, sport services stand as an important service field due to the customers' interaction with the physical environment, the relatively long periods spent in sport centers, and the presence of individuals in sport centers as participants (Theodorakis, Howat, Ko \& Avourdiadou, 2014). It is believed that customer expectations are to be taken into consideration in sport services which pose such an important place for the customers. The service qualities which are beyond the customer expectations and which influence customer satisfaction considerably are named as attractive requirements. It is stated that these services are not expected by the customers but, if provided, they will increase the customer satisfaction at a remarkable level (Chen \& Lin, 2007; Giritlioğlu \& Avcıkurt, 2010; Giritlioğlu \& Korkmaz, 2014). According to the Kano model, another group of service consists of ordinary (neutral) characteristics. The presence or absence of these qualities in a business are not important for the customers (Xu et al., 2009). For example, for a customer visiting a sport center, a beverage offered while waiting is an ordinary characteristic. The last service group is contrary characteristics. These are the services which are not expected to be offered by the customers, but they may disturb the customers if provided (Chen \& Lin, 2007). While the must-be requirements, one-dimensional requirements, and attractive requirements are named as requirements; ordinary and contrary characteristics are called as characteristics since they are not actual customer requirements (Chen, Chang, Hsu \& Yang, 2011; Sahney, 2011).

In short, the Kano model shows the interaction between the customer satisfaction and the performance level of the product or service. This interaction varies from attractive requirements towards must-be requirements. According to Sofyalioğlu \& Tunail (2012), the Kano model is considered as an effective approach enabling the classification of the customer requirements in different categories. 
According to Zeithaml, Parasuraman, \& Berry (1985), sport services' being qualified is seen as a determinant factor in the development of the businesses. If considered from the viewpoint of service businesses, private sport centers are defined as the places where the individuals' needs such as healthy life, wellness, losing weight, and power building are met (Yıldız, 2012). Service quality (Öztürk, 1996), which is more different than physical product quality and which has a more complicated nature to be understood, is an important issue for production process and the management phases of the businesses (Hsu, Chang, Wang, \& Lin, 2007). Because, service quality is expressed as the capability of a business to meet the customer requirements, and the quality perceived by the customer (Öztürk, 1996). Briefly, service quality may stem from the comparison of the actual service performance with the customer expectations. Service quality performance and measuring the customer reactions to this performance is one of the key factors of improving the service quality in an organization. In sport facilities and businesses, businesses will be able to maintain their existence as long as the customers' expectations which stem from external factors such as service quality are met (Emery, 2011; Taylor \& Godfrey, 2003).

Studies presenting various approaches to measure the service quality perceptions of the customers in sport and private sport centers can be found in the literature (Chelladurai \& Chang, 2000; Chelladurai, Scott \& Haywood-Farmer, 1987; Fernandez, Carrion \& Ruitz, 2012; Gencer, Demir \& Aycan, 2008; Ko \& Pastore, 2005; Theodorakis et al., 2014; Theodorakis, Kambitsis, \& Laios, 2001; Papadimitriou \& Karteliotis, 2000; Yildiz, 2011).

Sport businesses tend to plan and provide services in the most reasonable price and time to maintain their existence and to meet the sport-related expectations and requirements of the customers. For this reason, learning the customer demands and expectations is an important component to ensure that sport services are capable of meeting the customer requirements (Howard \& Crompton, 1980).

The current study has importance in terms of identifying the customer expectations and exploring service quality perceptions in sport centers, and determining what types of services should be offered in these businesses. In this study, within the frame of Kano Model, a commonly accepted model of expectation classification, it is aimed to explore the variables predicting the expectations of the sport center members and the levels of perceived service quality. It is considered that the research findings will put forward recommendations, along with related concrete evidences, to improve the service quality in private sport centers. Furthermore, the present study intends to help us anticipate to what extent the customers satisfaction and expectation determine their sport center preferences in the future.

\section{Method}

\subsection{Research Model}

In this study, descriptive and correlational scanning model methods were preferred among quantitative research methods.

\subsection{Research Group}

Participants of the present study consist of 680 private sport center members who have volunteered and who have been chosen on the basis of multistage sampling from the sport centers that functioned in Manisa province in 2017. The

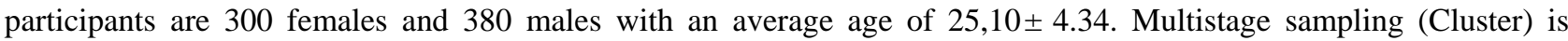
described as chosing samples from each selected groups when the sample turns out to be too big due the large numbers of selected groups (Karasar, 2014).

All the subjects in this study are voluntary participants. Consent request form for voluntary participation is attached to the introduction part of the survey. The form presents detailed information about the aim of the research, the contents, the duration, expected participant number, expectations from the participants, potential benefits of the study, voluntariness basis of participation, and confidentiality of any personal information. The participants are asked to sign the forms by reading and agreeing to take part in the study as voluntary participants.

Prior to data collection, ethical committee permission from Manisa Celal Bayar University, Institute of Social Sciences, Ethical Committee of Social and Humanity Sciences was obtained, the participants were informed about the study and their approval was obtained (Decision Date and Number: 12/07/2017: 11; 2017/3).

\subsection{Data Collection Tools}

In this study, personal information form prepared by the researchers and Perceived Service Quality Scale in Sport-Fitness Centers developed by Uçan (2007), and The Level of Meeting the Expectations from the Sport Centers Scale developed by Bingöl and Doğan (2010) are employed as data collection tools.

Personal Information Form: In this part, there are items to uncover the age, gender, programme fee perceptions and the frequency of doing sport.

"Sport-Fitness Centers Perceived Service Quality Scale (SFC-PSQS)": The measument tool developed by Uçan (2007) has a structure consisting of 5 points Likert type (1:Definitely disagree, 5: Definitely agree) 31 items and 6 subscales. 
In the reliability analyzes run with the data collected fort his study, the obtained consistency coefficient is $\alpha=0.96$. Psychometric features of the scale which do not have a total score quality is given below. Interaction Quality (10 Items) is composed of the features containing the members of sport-fitness centers and their interactions with staff working in these centers.

Outcome Quality (5 Items), are the items including the sport-fitness center members' opinions and evaluations regarding their purposes at the end of the services they receive. Physical Environment Quality (7 Items), are the items including the physical environment conditions where the service is provided to the members of sport-fitness centers. These items are about the qualities of waiting and resting areas, changing rooms and bathrooms, and the areas where sport is done. Exercise Tools and Equipments (3 Items) consists of items describing the qualities of tools and equipments used by the sport-fitness center members while doing sport. These items are expressions such as sufficient number of exercise tools and equipments, tools' and equipments' being convenient for the needs, and the safety and operability of these tools and equipments. Programme Quality (3 Items) consists of items stating the purposes of sport-fitness center members and the contents and qualities of programmes and activities offered in these centers. Environmental Conditions Quality (3 Items) are the items about the air-conditioning, lighting, and heating up the place.

Table 1. Sport-Fitness Centers Perceived Service Quality Scale (SFC-PSQS) Reliability coefficients

\begin{tabular}{lcc}
\hline Factors & $\begin{array}{c}\text { Reliability of Original } \\
\text { Research }(\alpha)\end{array}$ & $\begin{array}{c}\text { Reliability for Current } \\
\text { Research }(\alpha)\end{array}$ \\
\hline Interaction Quality & 0.95 & 0.92 \\
Outcome Quality & 0.92 & 0.89 \\
Physical Environment Quality & 0.85 & 0.90 \\
Exercise Tools and Equipments & 0.82 & 0.85 \\
Programme Quality & 0.83 & 0.81 \\
Environmental Conditions Quality & 0.77 & 0.77 \\
\hline
\end{tabular}

Centers Expectations State Questionnaire: The questionnaire was developed by Bingöl \& Doğan (2010), and consists of 18 all positive item. Each item is accompanied by a 5-point Likert scale (1:Definitely disagree, 5: Definitely agree).

\subsection{Collection of Data}

In the collection of the research data 5 trained assistants along with the researchers were employed in this study. The assistants were informed in detail about the points to be considered while filling in the survey form. The surveys were completed through the method of face to face interviews in sport centers chosen on the basis of multistage sampling. A total of 770 surveys were collected from the participants. The researchers eliminated 90 surveys which were found to be lacking or miscompleted, and accepted 680 surveys as valid and analyzed them. 88,3\% reliable feedback was attained from the measurement tools employed.

\subsection{Statistical Analysis of Data}

SPSS 22 Package Programme is used to analyze the data collected in this study. Skewness and Curtosis values are considered in the normality tests of the data. Mean, standard deviation and correlation (Pearson Correlation) values are analyzed for the subscales of Expectation Scale and Perceived Service Quality Scale. While the significance between two means test (the Independent Samples T-Test) is run to detect the difference between scale subdimensions with binary variables, Multiple Linear Regression Analysis is used to measure the probability of bistable results through one or more independent variables. The validity of the Centers Expectations State Questionnaire is investigated through factor analysis and the reliability of the scale is further tested via Cronbach's alpha values.

\section{Findings}

In this part of the study, the analyzes regarding the validity and reliability tests of The Level of Meeting the Expectations from the Sport Centers and their findings are presented.

\subsection{Expectation Scale Validity and Reliability Analysis}

Due to the lack of sufficient information about the validity and reliability of Centers Expectations State Questionnaire, validity and reliability analyzes are repeated by gaining permission from Bingöl and Doğan (2010).

The results of the construct validity and reliability for expectation scale are in Table 2. Initially, Explanatory Factor Analysis (EFA) is run. Kayser-Meyer-Olkin Measure of Sampling Adequacy (KMO) value and Barlett's Test of Sphericity results show that the existing data is convenient for the analysis. After leaving out the items which do not have the sufficient factor load value (0.40) following the EFA, it is seen that 2 factors, each consisting of 7 items, and having an Eigenvalue bigger than 1 have emerged. Total varience explained related to two factors is 65,48\%. First factor is named as "Expectation-Physical Development" and the second factor as "Expectation-Psyhco-Social Development". The highest score to be attained from the dimensions being evaluated over the total score is 35 while the lowest is 7 . 
Confirmatory Factor Analyses (CFA) is applied to the bidimensional structure obtained as a result of EFA. Improvements in the CFA analysis are done considering the suggestions of modification. According to the results obtained, while it is found that the chi-square value is slightly above the acceptable level according to the degree of freedom, other indexes (RMSEA, SRMR, GFI, AGFI, CFI, NFI, NNFI) are identified to be between the limits of good and sufficient.

It is detected that the correlation values for all items vary between 0.62 and 0.77 . In the independent samples t-test comparison of lower $27 \%$ and upper $27 \%$ groups, significant differences $(p<0,001)$ are detected. Thus, it is seen that the distinctiveness function of the scale is sufficient. When the whole scale's and subdimensions' Cronbach's Alpha internal consistency values are examined, alpha coefficient for the first factor is found as $\alpha=0,91$, and alpha coefficient for the second factor as $\alpha=0,94$. A strong positive correlation $(r=0,74)$ is seen between the two factors. The definitions of the subdimensions are as below:

Table 2. Validity and reliability table of The Level of Meeting the Expectations from the Sport Centers Scale

\begin{tabular}{|c|c|c|c|c|c|c|}
\hline & \multicolumn{2}{|c|}{ EFA Results } & \multirow{2}{*}{$\begin{array}{l}\text { Corrected } \\
\text { Item-Total } \\
\text { Correlation }\end{array}$} & \multirow{2}{*}{$\begin{array}{c}\text { High-Low } \\
\text { Groups \%27 } \\
\text { Differences** }\end{array}$} & \multicolumn{2}{|c|}{ CFA Results } \\
\hline & 1. Factor & 2. Factor & & & Fit Index & $\begin{array}{l}\text { Goodness of } \\
\text { Fit Values }\end{array}$ \\
\hline Item 1 & 0.64 & & 0.63 & -40.10 & $\chi^{2}$ & 241.06 \\
\hline Item 2 & 0.73 & & 0.73 & -38.80 & sd & 47 \\
\hline Item 3 & 0.80 & & 0.77 & -41.86 & $\chi^{2} / \mathrm{sd}$ & 5.12 \\
\hline Item 4 & 0.84 & & 0.69 & -46.34 & RMSEA & 0.078 \\
\hline Item 5 & 0.79 & & 0.72 & -49.74 & SRMR & 0.026 \\
\hline Item 6 & 0.71 & & 0.67 & -48.66 & GFI & 0.95 \\
\hline Item 7 & 0.66 & & 0.75 & -47.62 & AGFI & 0.89 \\
\hline Item 8 & & 0.61 & 0.73 & -47.61 & CFI & 0.99 \\
\hline Item 9 & & 0.73 & 0.68 & -47.13 & NFI & 0.99 \\
\hline Item 10 & & 0.80 & 0.72 & -40.51 & NNFI & 0.98 \\
\hline Item 11 & & 0.80 & 0.70 & -45.41 & & \\
\hline Item 12 & & 0.75 & 0.70 & -47.43 & $\mathrm{CN}$ & 201.04 \\
\hline Item 13 & & 0.67 & 0.67 & -46.28 & & \\
\hline Item 14 & & 0.70 & 0.71 & -47.77 & & \\
\hline Variance & 33.16 & 32.32 & & & & \\
\hline \multicolumn{2}{|c|}{ Total Variance Explained } & 65.48 & & & & \\
\hline \multicolumn{2}{|c|}{$\begin{array}{ll}\text { Cronbach's } & 0.91\end{array}$} & 0.90 & & & & \\
\hline \multicolumn{2}{|c|}{ Total Cronbach's Alpha } & 0.94 & & & & \\
\hline \multicolumn{2}{|c|}{$\begin{array}{l}\text { Kaiser-Mayer-Olkin } \\
\text { Measure of Sampling Adequec }\end{array}$} & 0.94 & & & & \\
\hline Measure of Sam & $\begin{array}{c}\text { pling Adeque } \\
\chi^{2}=914 \\
\mathrm{f}=153 \\
\mathrm{P}=0.00\end{array}$ & & & & $\bar{X}$ & S \\
\hline \multicolumn{3}{|c|}{ 2. Psychosocial Changes } & & 1. & 27.03 & 5.68 \\
\hline $\begin{array}{r}\text { 1. Physical } \\
\text { Changes }\end{array}$ & $\mathrm{r}=0.74^{*}$ & & & 2. & 27.17 & 5.75 \\
\hline
\end{tabular}

Expectation- Physical Changes: In this dimension, there are items related to physical development, physical beauty attainment, having a shapeful body, the body's gaining the habit of standing straight, strength development, endurance development, and the level of meeting the expectations to have a flexible body in the activities done in sport centers.

Expectation- Psychosocial Changes: This dimension consists of items attempting to measure the habit of doing sport regularly, discovering sportive ability, discovering the limits of personal capacity, developing interpersonal relationships, maintaining psychological balance, self-confidence, and expectations to minimize the daily emotional states such as anger, tension, stress.

\subsection{Descriptive Statistics Findings}

In Table 3, some personal information and descriptive statistics related to SFC-PSQS and the subdimensions of the Expectation Scale are presented.

When Table 3 is analyzed, $64.1 \%$ of the participants with an average age of $25,10( \pm 4,34)$ state that membership fees of sport centers are not expensive. While the participants' physical development expectations average is found as 27,03 $( \pm 5,67)$; and the psycho-social development expection average as $27,17( \pm 5,75)$; among the subdimensions of service quality subdimensions, outcome quality has the highest average with 3,97 $( \pm 0,87)$ and physical environment quality has the lowest average score with 3,65 $( \pm 0,84)$. 
Table 3. Descriptive Statistics

\begin{tabular}{|c|c|c|c|c|c|c|c|c|}
\hline & & $\mathrm{f}$ & $\%$ & Total & $\bar{X}$ & $\mathrm{SD}$ & Min. & Max. \\
\hline \multirow{2}{*}{ Membership Fees } & Expensive & 244 & 35.9 & \multirow{2}{*}{680} & & & & \\
\hline & Reasonable & 434 & 64.1 & & & & & \\
\hline Age & & & & 680 & 25.10 & 4.34 & 18.00 & 49.00 \\
\hline Duration of Membership (Day) & & & & 680 & 217.00 & 360.64 & 7.00 & 3650.00 \\
\hline Expectation- Physical Changes & & & & 680 & 27.03 & 5.67 & 7.00 & 35.00 \\
\hline Expectation- Psychosocial Changes & & & & 680 & 27.17 & 5.75 & 7.00 & 35.00 \\
\hline Physical Environmental Quality & & & & 680 & 3.65 & 0.84 & 1.00 & 5.00 \\
\hline Interaction Quality & & & & 680 & 3.86 & 0.78 & 1.00 & 5.00 \\
\hline Outcome Quality & & & & 680 & 3.97 & 0.87 & 1.00 & 5.00 \\
\hline Programme Quality & & & & 680 & 3.75 & 0.87 & 1.00 & 5.00 \\
\hline Environmental Conditions Quality & & & & 680 & 3.80 & 0.84 & 1.00 & 5.00 \\
\hline
\end{tabular}

3.3 Findings of the Test of Differences Between Some Variables and Subdimensions of the Expectation Scale.

The comparison scores of the participants' genders and the variable of the perceptions of membership fees with their expectations are given in Table 4.

Table 4. The results of the difference test between some variables and the subdimensions of the expectation scale (Independent $\mathrm{t}$ test)

\begin{tabular}{|c|c|c|c|c|c|c|c|}
\hline Independent Variables & Groups & $\mathrm{f}$ & $X$ & S.D & $\mathrm{df}$ & $\mathrm{t}$ & $\mathrm{p}$ \\
\hline \multirow{2}{*}{ Physical Changes } & Female & 300 & 26.93 & 5.24 & \multirow{2}{*}{671.03} & \multirow{2}{*}{-0.39} & \multirow{2}{*}{0.70} \\
\hline & Male & 380 & 27.10 & 6.00 & & & \\
\hline \multirow{2}{*}{ Psychosocial Changes } & Female & 300 & 26.91 & 5.35 & \multirow{2}{*}{669.14} & \multirow{2}{*}{-1.03} & \multirow{2}{*}{0.30} \\
\hline & Male & 380 & 27.37 & 6.05 & & & \\
\hline \multirow{2}{*}{ Physical Changes } & Expensive & 244 & 26.00 & 5.80 & \multirow{2}{*}{678} & \multirow{2}{*}{-3.60} & \multirow{2}{*}{$\mathbf{0 . 0 0}$} \\
\hline & Reasonable & 436 & 27.61 & 5.52 & & & \\
\hline \multirow{2}{*}{ Psychosocial Changes } & Expensive & 244 & 26.08 & 6.34 & \multirow{2}{*}{433.44} & \multirow{2}{*}{-3.72} & \multirow{2}{*}{0.00} \\
\hline & Reasonable & 436 & 27.77 & 5.30 & & & \\
\hline
\end{tabular}

When Table 4 results are examined, there is no significant difference between the gender and the physical development and psychosocial development which are among the expectation scale subdimensions. Significant differences in favor of those stating that the fees are not expensive are detected between the physical development (27.61 \pm 5.52$)$ along with psychosocial development $(27.77 \pm 5.30)$, and the perception of membership fees $(\mathrm{p}<0.05)$.

3.4 Correlation Findings

Table 5. The relationships among some variables, SFC-PSQS subdimensions and expectation (Pearson correlation)

\begin{tabular}{lccccc}
\hline & \multicolumn{3}{c}{$\begin{array}{c}\text { Expectation- Physical } \\
\text { Changes }\end{array}$} & \multicolumn{2}{c}{ Expectation- Psychosocial } \\
& \multicolumn{2}{c}{ Changes } \\
& $\mathrm{n}$ & $\mathrm{r}$ & $\mathrm{p}$ & $\mathrm{r}$ & $\mathrm{p}$ \\
\hline Frequency of Going to Sport Center & 680 & $\mathbf{0 . 3 2}$ & $\mathbf{0 . 0 0}$ & $\mathbf{0 . 2 4}$ & $\mathbf{0 . 0 0}$ \\
Duration of Membership (Day) & 680 & -0.03 & 0.44 & -0.07 & 0.06 \\
Physical Environmental Quality & 680 & $\mathbf{0 . 5 5}$ & $\mathbf{0 . 0 0}$ & $\mathbf{0 . 5 3}$ & $\mathbf{0 . 0 0}$ \\
Interaction Quality & 680 & $\mathbf{0 . 6 9}$ & $\mathbf{0 . 0 0}$ & $\mathbf{0 . 6 4}$ & $\mathbf{0 . 0 0}$ \\
Outcome Quality & 680 & $\mathbf{0 . 6 6}$ & $\mathbf{0 . 0 0}$ & $\mathbf{0 . 6 2}$ & $\mathbf{0 . 0 0}$ \\
Programme Quality & 680 & $\mathbf{0 . 6 6}$ & $\mathbf{0 . 0 0}$ & $\mathbf{0 . 6 0}$ & $\mathbf{0 . 0 0}$ \\
Exercise Tools and Equipments & 680 & $\mathbf{0 . 6 1}$ & $\mathbf{0 . 0 0}$ & $\mathbf{0 . 5 7}$ & $\mathbf{0 . 0 0}$ \\
Environmental Conditions Quality & 680 & $\mathbf{0 . 5 0}$ & $\mathbf{0 . 0 0}$ & $\mathbf{0 . 4 9}$ & $\mathbf{0 . 0 0}$ \\
\hline
\end{tabular}

When Table 5 is analyzed, while there is no significant correlation between membership duration and the subdimensions of expectation scale ( $p>.05$ ), a medium level correlation between going to a sport center and physical development $(r=.32 ; p<.05)$, and a low level positive relationship between psychosocial development and frequency of going to a sport center are detected $(r=.24 ; \mathrm{p}<.05)$. This situation shows that as the frequency of participants' going to a sport center increases, even slightly, so do their expectation levels.

When the subdimensions of the expectation scale and the SFC-PSQS are compared, it is observed that all the subdimensions has medium or high level significant positive correlations with the expectation. As the participants' perception level of the quality of service in the sport centers increase, their expectation levels also generally increase at a remarkable level. 


\subsection{Findings of Linear Regression Analysis}

Table 6. The results of multiple linear regression analysis regarding SFC-PSQS subdimensions' explanation of Expectation dimensions by genders

\begin{tabular}{|c|c|c|c|c|c|c|c|}
\hline & & & & lardized & Standardized & & \\
\hline & Groups & Variables & & cients & Coefficients & $\mathrm{t}$ & $\mathrm{p}$ \\
\hline & & & $\mathrm{B}$ & Std. Error & Beta & & \\
\hline & & Constant & 3,87 & 1,06 & & 3,66 & 0,00 \\
\hline & & Physical Environmental Quality & 0,11 & 0,33 & 0,02 & 0,34 & 0,74 \\
\hline & & Interaction Quality & 2,74 & 0,55 & 0,37 & 4,96 & $\mathbf{0 , 0 0}$ \\
\hline & Female & Outcome Quality & 1,56 & 0,37 & 0,25 & 4,24 & $\mathbf{0 , 0 0}$ \\
\hline & & Programme Quality & 1,49 & 0,37 & 0,24 & 4,08 & $\mathbf{0 , 0 0}$ \\
\hline E & & Exercise Tools and Equipments & 0,57 & 0,33 & 0,09 & 1,76 & 0,08 \\
\hline$\underline{0}$ & & Environmental Conditions Quality & $-0,51$ & 0,32 & $-0,08$ & $-1,59$ & 0,11 \\
\hline$\cdot \frac{0}{\infty}$ & $\mathrm{R}=0,803$ & $\mathrm{R}^{2}=0,645$ & $\mathrm{p}=0,00$ & & & & \\
\hline $\bar{\nu}$ & & Constant & 4,03 & 1,16 & & 3,47 & 0,00 \\
\hline. $\bar{g}$ & & Physical Environmental Quality & 0,73 & 0,36 & 0,10 & 2,05 & 0,04 \\
\hline ¿ू. & & Interaction Quality & 1,22 & 0,46 & 0,17 & 2,65 & $\mathbf{0 , 0 1}$ \\
\hline & Male & Outcome Quality & 1,61 & 0,38 & 0,24 & 4,22 & $\mathbf{0 , 0 0}$ \\
\hline & & Programme Quality & 1,61 & 0,37 & 0,25 & 4,38 & $\mathbf{0 , 0 0}$ \\
\hline & & Exercise Tools and Equipments & 0,83 & 0,37 & 0,13 & 2,24 & $\mathbf{0 , 0 3}$ \\
\hline & & Environmental Conditions Quality & 0,02 & 0,37 & 0,00 & 0,04 & 0,97 \\
\hline & $\mathrm{R}=0,744$ & $\mathrm{R}^{2}=0,554$ & $\mathrm{p}=0,00$ & & & & \\
\hline & & Constant & 4,68 & 1,21 & & 3,86 & 0,00 \\
\hline & & Physical Environmental Quality & 0,62 & 0,38 & 0,10 & 1,63 & 0,11 \\
\hline & & Interaction Quality & 3,38 & 0,63 & 0,45 & 5,34 & $\mathbf{0 , 0 0}$ \\
\hline & Female & Outcome Quality & 0,87 & 0,42 & 0,13 & 2,07 & 0,04 \\
\hline స్త్ర & & Programme Quality & 0,91 & 0,42 & 0,14 & 2,18 & $\mathbf{0 , 0 3}$ \\
\hline$\underline{\pi}$ & & Exercise Tools and Equipments & 0,03 & 0,37 & 0,00 & 0,07 & 0,95 \\
\hline$\overline{0}$ & & Environmental Conditions Quality & $-0,01$ & 0,36 & $-0,00$ & $-0,03$ & 0,97 \\
\hline$\frac{8}{0}$ & $\mathrm{R}=0,774$ & $\mathrm{R}^{2}=0,553$ & $\mathrm{p}=0,00$ & & & & \\
\hline$\rho_{1}^{n}$ & & Constant & 5,30 & 1,25 & & 4,25 & 0,00 \\
\hline . & & Physical Environmental Quality & 0,47 & 0,38 & 0,07 & 1,22 & 0,23 \\
\hline ¿ & & Interaction Quality & 0,34 & 0,49 & 0,05 & 0,69 & 0,49 \\
\hline 馬 & Male & Outcome Quality & 2,27 & 0,41 & 0,34 & 5,55 & $\mathbf{0 , 0 0}$ \\
\hline & & Programme Quality & 1,33 & 0,40 & 0,20 & 3,36 & $\mathbf{0 , 0 0}$ \\
\hline & & Exercise Tools and Equipments & 0,89 & 0,40 & 0,14 & 2,23 & $\mathbf{0 , 0 3}$ \\
\hline & & Environmental Conditions Quality & 0,43 & 0,40 & 0,06 & 1,07 & 0,29 \\
\hline & $R=0,703$ & $\mathrm{R}^{2}=0,494$ & $\mathrm{p}=0,00$ & & & & \\
\hline
\end{tabular}

When the findings are evaluated in terms of genders, it is seen that SFC-PSQS subdimensions' power to explain Expectation-Physical Development is a little higher among women $\left(R^{2}=0,645\right)$ than men $\left(R^{2}=0,554\right)$. According to the results revealing significant relationships $(\mathrm{p}<0,05)$, the women's Expectation-Physical Development level is explained, in terms of standardized regression coefficient relative importance order, by interaction quality, outcome quality and program quality at a level of $64 \%$. Among women, on the other hand, according to the order of relative importance, programme quality, outcome quality, interaction quality, exercise tools and equipments quality and physical environment quality explain by $55 \%$. 
It can be seen that the SFC-PSQS subdimensions' power to explain Expectation-Psycho-social Development dimension is again slightly higher among women $\left(R^{2}=0,553\right)$ than men $\left(R^{2}=0,494\right)$. Significant $(p<0,05)$ predictor variables order among women is as outcome quality, programme quality, and exercise tools and equipments quality.

Table 7. Multiple linear regression analysis results regarding the explanation of Expectation dimensions by SFC-PSQS subdimensions according to the membership fee perceptions

\begin{tabular}{|c|c|c|c|c|c|c|c|}
\hline & \multirow[t]{2}{*}{ Groups } & \multirow[t]{2}{*}{ Variables } & \multicolumn{2}{|c|}{$\begin{array}{l}\text { Unstandardized } \\
\text { Coefficients }\end{array}$} & \multirow{2}{*}{$\begin{array}{c}\text { Standardized } \\
\text { Coefficients } \\
\text { Beta }\end{array}$} & \multirow[t]{2}{*}{$\mathrm{t}$} & \multirow[t]{2}{*}{$\mathrm{p}$} \\
\hline & & & $\mathrm{B}$ & Std. Error & & & \\
\hline \multirow{16}{*}{ 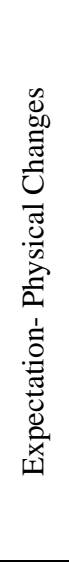 } & \multirow{7}{*}{ Expensive } & Constant & 3,52 & 1,25 & & 2,82 & 0,00 \\
\hline & & Physical Environmental Quality & $-0,36$ & 0,43 & $-0,06$ & $-0,85$ & 0,39 \\
\hline & & Interaction Quality & 2,73 & 0,60 & 0,35 & 4,52 & $\mathbf{0 , 0 0}$ \\
\hline & & Outcome Quality & 2,19 & 0,42 & 0,33 & 5,26 & $\mathbf{0 , 0 0}$ \\
\hline & & Programme Quality & 1,31 & 0,44 & 0,21 & 2,99 & $\mathbf{0 , 0 0}$ \\
\hline & & Exercise Tools and Equipments & 0,66 & 0,40 & 0,10 & 1,65 & 0,10 \\
\hline & & Environmental Conditions Quality & $-0,47$ & 0,37 & $-0,07$ & $-1,26$ & 0,21 \\
\hline & $\mathrm{R}=0,793$ & $\mathrm{R}^{2}=0,628 \quad \mathrm{~F}=66,78$ & $\mathrm{p}=0,00$ & & & & \\
\hline & \multirow{7}{*}{ Reasonable } & Constant & 3,27 & 1,09 & & 2,98 & 0,00 \\
\hline & & Physical Environmental Quality & 1,16 & 0,31 & 0,16 & 3,71 & $\mathbf{0 , 0 0}$ \\
\hline & & Interaction Quality & 3,27 & 1,09 & 0,21 & 3,47 & $\mathbf{0 , 0 0}$ \\
\hline & & Outcome Quality & 1,17 & 0,35 & 0,18 & 3,32 & $\mathbf{0 , 0 0}$ \\
\hline & & Programme Quality & 1,43 & 0,35 & 0,21 & 4,05 & $\mathbf{0 , 0 0}$ \\
\hline & & Exercise Tools and Equipments & 1,09 & 0,33 & 0,17 & 3,32 & $\mathbf{0 , 0 0}$ \\
\hline & & Environmental Conditions Quality & $-0,15$ & 0,34 & $-0,02$ & $-0,44$ & 0,66 \\
\hline & $\mathrm{R}=0,750$ & $\mathrm{R}^{2}=0,563 \quad \mathrm{~F}=92,15$ & $\mathrm{p}=0,00$ & & & & \\
\hline \multirow{16}{*}{ 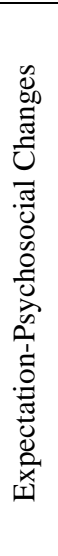 } & \multirow{7}{*}{ Expensive } & Constant & 1,81 & 1,45 & & 1,25 & 0,21 \\
\hline & & Physical Environmental Quality & 0,20 & 0,50 & 0,03 & 0,40 & 0,69 \\
\hline & & Interaction Quality & 3,18 & 0,70 & 0,37 & 4,52 & $\mathbf{0 , 0 0}$ \\
\hline & & Outcome Quality & 2,27 & 0,49 & 0,31 & 4,67 & $\mathbf{0 , 0 0}$ \\
\hline & & Programme Quality & 0,06 & 0,51 & 0,01 & 0,11 & 0,91 \\
\hline & & Exercise Tools and Equipments & 1,24 & 0,47 & 0,17 & 2,63 & $\mathbf{0 , 0 1}$ \\
\hline & & Environmental Conditions Quality & $-0,39$ & 0,43 & $-0,05$ & $-0,89$ & 0,37 \\
\hline & $\mathrm{R}=0,759$ & $\mathrm{R}^{2}=0,576 \quad \mathrm{~F}=53,70$ & $\mathrm{p}=0,00$ & & & & \\
\hline & \multirow{7}{*}{ Reasonable } & Constant & 6,42 & 1,17 & & 5,49 & 0,00 \\
\hline & & Physical Environmental Quality & 0,79 & 0,33 & 0,11 & 2,36 & $\mathbf{0 , 0 2}$ \\
\hline & & Interaction Quality & 0,78 & 0,46 & 0,11 & 1,69 & 0,09 \\
\hline & & Outcome Quality & 1,62 & 0,38 & 0,26 & 4,29 & $\mathbf{0 , 0 0}$ \\
\hline & & Programme Quality & 1,51 & 0,38 & 0,23 & 3,99 & $\mathbf{0 , 0 0}$ \\
\hline & & Exercise Tools and Equipments & 0,31 & 0,35 & 0,05 & 0,89 & 0,37 \\
\hline & & Environmental Conditions Quality & 0,41 & 0,36 & 0,06 & 1,13 & 0,26 \\
\hline & $R=0,678$ & $\mathrm{R}^{2}=0,459 \quad \mathrm{~F}=60,78$ & $\mathrm{p}=0,00$ & & & & \\
\hline
\end{tabular}

When Table 7 is analyzed, it is observed that the power of SFC-PSQS subdimensions to explain Expectation-Physical Development dimension according to membership fee perception is higher in the expensive group $\left(R^{2}=0,628\right)$ than the reasonable group $\left(R^{2}=0,563\right)$. In the group stating that the fee is expensive, the most important significant predictive variables are interaction quality, outcome quality, and programme quality; while in the reasonable fee group, these variables are found to be programme quality, interaction quality, outcome quality, exercise tools and equipments, and physical environment quality.

The SFC-PSQS subdimensions' power to explain Expectation-Psycho-social Development dimension is found to be higher in the expensive group $\left(R^{2}=0,576\right)$ than the reasonable group $\left(R^{2}=0,459\right)$. In the group stating that the fee is high, the most important predictive variables are respectively the interaction quality, outcome quality and exercise tools and equipments. In the reasonable group, on the other hand, the most important predictive variables are respectively the outcome quality, programme quality, and physical environment quality variables.

\section{Discussion and Conclusion}

It is stated that sport can cause emotional, moral, physical and psychosocial developments besides health and welfare (LaVoi, 2007). Likewise, sport is also an important effect on individuals' individual identity acquisitions in addition to enable people to provide group membership and social identity (Eitzen \& Sage, 2009). For sport centers, what customer expectations are and to what extent are these expectations provided are important factors in the success and continuity of businesses. Today, technological developments play an important role in offering comfortable service to customers of sport centers. Changing social conditions, especially urbanization and living conditions, can also affect individual expectations provided by businesses. The customers, who are expecting more qualified service, won't be satisfied with businesses, which they get service by, if their requests are not supplied. For this reason, sport centers need to provide 
customers with services, as well as essential ones, which are exciting or which customers can expect on the purpose of providing qualified services. Service quality and expected service for customers are the anticipated performances that customers wish to have from businesses. As well as this situation may be a physical and psychosocial need for sport center customers, it may also be services arising from physical characteristics of businesses, just as cleaning, technical equipment and environmental situations. The only factor to ensure sustainability and continuity of sport centers is not sufficient. Because customer expectations, which may affect individual consumer satisfaction, equipment, sport center experience, customer loyalty, interaction, socialization and physical appearance need to be considered (Yıldiz, Polat, Sönmezoğlu \& Çokpartal, 2016). Customer expectations can be met by providing a qualified service. The process between customer expectations and proffered service performance will also give an idea about the quality of service which is provided. In a sport center with a good physical infrastructure and adequate equipment, it is stated that customers are more interested in the level of satisfaction of proffered sport services than physical characteristics of facilities (Imamoğlu, 1998). Therefore, customer satisfaction is increasing in direct proportion with qualified service delivery. The recent researches have determined that consumers' service quality perceptions are obtained by comparing customers' previous service expectations with the actual performance of the next service (Parasuraman, Zeithaml \& Berry, 1985; 1988). It can be said that the physical $(x=27.03 \pm 5.67)$ and psychosocial $(x=27.17 \pm 5.75)$ expectations of sports center members who participated in the current research are at a good level.

From the perceived quality of service scale sub-dimensions, it is seen that the customer has the highest average of $3.97( \pm .87)$, which emphasizes the benefit of the service. The output quality is indicated as the benefits that customers want to see after attending sports programs (Chang \& Chelladurai, 2003). In a similar research Üzüm et al. 2016, it is determined that interaction quality, output quality, physical environmental quality, program quality, exercise equipment and environmental conditions quality are above average of service quality perception level in sub-dimensions. Today, when we have a rapid social change, individuals tend to be good physically and spiritually and to be good at socializing. For this reason, it can be expressed that individuals are expecting some benefits from the private sport centers in their free time.

It appears that the expectations of customers participating in the survey differ in favour of the group, indicating that membership fees are not expensive in terms of variability. It can be said that the membership fee does not affect the physical and psychosocial expectations of the customers. In conjunction with program compatibility at a sport center and membership fee are seen as an important factor for customers, the quality of the program and the variety of exercise devices and equipment can be considered as an important factor in meeting customer expectations. Individuals participating in the current survey have specified that the sport center membership fees are reasonable. The relevant literature posits that program intensity and affordable membership fees are significant factors in terms of achieving higher customer satistaction (Afthinos, Theodorakis \& Nassis, 2005; Papadimitriou \& Karteliotis, 2000). Research also demonstrates that members' perceptions of higher quality service and satisfaction with sport centers as a function of fullfilled expectations significantly decrease customers' price sensitivity (Yıldız, 2012).

When the results of correlation between sport center customer expectations and perceived service quality sub-dimensions are examined, there is a positive level of moderate relationship between expectation-physical and expectation-psychosocial development sub-dimensions and physical environment, interaction, output, program, exercise devices and equipment and environment conditions. The obtained results can be expressed in the way that sport centers can meet the expectations of customers when they provide qualified service. It can be said that as long as the level of service quality perceptions in sport centers increases, the expectation level may increase significantly in general terms. According to Bitner (1992), the perceived quality of service is expressed as "direction and degree of difference between customer expectations and perceptions". Briefly, the expected service and the perceived service give the service quality (Gronross, 1988). Sports businesses will be able to sustain their assets if customer expectations are met due to working customer-focused. Because the expected service consists of customers' expectations devoted to proffered service while the perceived service consists of their perceptions devoted to how proffered service is presented to them customers (Brady and Cronin, 2001). According to Afthinos et al. (2005), meeting customer expectations reflects a business' service delivery and interaction with employees. Similarly, Chelladurai \& Chang (2000) has emphasized the importance of interaction in service process by mentioning the importance of the relationships between service and customers. The researches emphasize the importance of meeting customer expectations and providing qualified service in terms of keeping customers permanent (Afthinos, et al., 2005; Parasuraman et al., 1988). It can also be said that the tendency to use service purchased by customers satisfied with their expectation provided and service they have gotten will continue and the quality of the service offered to the customers will spread around the customer. In the researches related to sport centers, it is stated that there is a significant relation between service quality perception, expectation and customer satisfaction (de Barros \& Gonçalves, 2009; Yıldız, Onağ \& Onağ, 2013; Yıldız, Duyan \& Günel, 2018).

As a result, it is obvious that there are various approaches and models to measure service quality perceptions and customer expectations (Fernandez, et al., 2012; Gronross, 1988; Parasuraman et al., 1988; Uçan, 2007). It can be 
thought that social changes and transformations play an active role in bringing out conscious consumers. For this reason, it can be said that sport center members do not evaluate the sports centers they went to in one dimension. The sport centers' physical elements and physical development factors, just as programs, dressing rooms, showers, cleaning, security, lighting, meet the basic needs of individuals. It is thought, however, that the environment in which they can socialize and the fact that human relationships are in the forefront can be important for meeting the basic expectations of customers. Customers want the services they get to be of high-quality and their expectations are met more than they ask. However, it is predicted that the physical and psychosocial factors influenced by expectation can significantly affect perception of service quality. Because the quality of service and meeting client expectations are an important indicator of the ability of businesses to sustain their assets, multi-factorial research should be done to understand the nature of service quality and customer expectations. Although the quality of service and measuring tools are sufficient, it is suggested that customer expectations should be added to new research topics in the changing world conditions and extensive researches should be carried out. Particularly in service quality studies, only female customers will make an important contribution to reveal the perception of women's expectations and service quality.

\section{References}

Afthinos, Y., Theodorakis, N. D., \& Nassis, P. (2005). Customers' expectations of service in Greek fitness centers: Gender, age, type of sport center, and motivation differences. Managing Service Quality: An International Journal, 15(3), 245-258. https://doi.org/10.1108/09604520510597809

Bingöl, A., \& Doğan, A. A. (2010). The satisfaction amount of people who continues sport centers from sport and sport centers. Selçuk University Journal of Physical Education and Sport Science, 12(3), 199-203. http://dergipark.gov.tr/tsed/archive

Bitner, M. J. (1992). Servicescapes: The impact of physical surroundings on customers and employees. The Journal of Marketing, 57-71. https://doi.org/10.2307/1252042

Brady, M. K., \& Cronin, J. J. (2001). Some new thoughts on conceptualizing perceived service quality: A hierarchical approach. Journal of Marketing, 65(3), 34-49. https://doi.org/10.1509/jmkg.65.3.34.18334

Chang, K., \& Chelladurai, P. (2003). System-based quality dimensions in fitness services: Development of the scale of quality. The Service Indsutries Journal, 23(5), 65-83. https://doi.org/10.1080/02642060308565624

Chelladurai, P., \& Chang, K. (2000). Targets and standards of quality in sport services. Sport Management Review, 3, $1-$ 22. https://doi.org/10.1016/S1441-3523(00)70077-5

Chelladurai, P., Scott, F. L., \& Haywood-Farmer, J. (1987). Dimensions of fitness services: Development of a model. Journal of Sport Management, 1, 159- 172. https://doi.org/10.1123/jsm.1.2.159

Chen, C. C., \& Chuang, M. C. (2008). Integrating the Kano model into a robust design approach to enhance customer satisfaction with product design. International Journal of Production Economics, 114(2), 667-681. https://doi.org/10.1016/j.ijpe.2008.02.015

Chen, L. H., \& Lin, H. C. (2007). Integrating Kano's model into E-learning satisfaction. In Industrial Engineering and Engineering Management, 2007 IEEE International Conference on (pp. 297-301).

Chen, M. C., Chang, K. C., Hsu, C. L., \& Yang, I. C. (2011). Understanding the relationship between service convenience and customer satisfaction in home delivery by Kano model. Asia Pacific Journal of Marketing and Logistics, 23(3), 386-410. https://doi.org/10.1108/13555851111143277

Chien, T. K. (2007). Using the learning satisfaction improving model to enhance the teaching quality. Quality assurance in Education, 15(2), 192-214. https://doi.org/10.1108/09684880710748947

de Barros, C., \& Gonçalves, L. (2009). Investigating individual satisfaction in health and fitness training centres. International Journal of Sport Management and Marketing, 5(4), 384-395. https://doi.org/10.1504/IJSMM.2009.023367

Dixon, M. A., \& Warner, S. (2010). Employee satisfaction in sport: Development of a multi-dimensional model in coaching. Journal of Sport Management, 24(2), 139-168. https://doi.org/10.1123/jsm.24.2.139

Eitzen, D. S., \& Sage, G. H. (2009). Sociology of north American sport. New York: Oxford University Press.

Emery, P. (2011). The sports management toolkit. Newyork: Taylor \& Francis.

Fernandez, J. G., Cepeda Carrion, G., \& Martin Ruiz, D. (2012). Customer satisfaction and its relation to perceived quality in fitness centres: Calidfit scale. Revista de Psicología del Deporte,21(2), 309-319. https://ddd.uab.cat/record/105917?ln=ca

Gencer, R. T., Demir, C., \& Aycan, A. (2008). Variables affecting sport tourists' service quality perceptions in ski resorts. 
Ege Academic Review, 8(2), 437-450. http://www.onlinedergi.com/eab/arsiv/arama.aspx

Giritlioğlu, İ., \& Avcıkurt, C. (2010). An Investigation directing at the undergraduated tourism students on the classification of school websites using kano model. Journal of Travel and Hospitality Management, 7(3), 64-78. http://www.soidergi.com.tr/wp-content/uploads/2012/01/lisans-duzeyinde-turizm-egitimi.pdf

Giritlioğlu, İ., \& Korkmaz, H. (2014). A Kano model classification of tourism faculty students' service expectations as tourism consumers from night clubs. Anadolu University Journal of Social Sciences, 14(4), 153-165. https://doi.org/10.18037/ausbd.19882

Grönroos, C. (1988). Service quality: The six criteria of good perceived service. Review of Business, 9(3), 10-13.

Högström, C., Rosner, M., \& Gustafsson, A. (2010). How to create attractive and unique customer experiences: An application of Kano's theory of attractive quality to recreational tourism. Marketing Intelligence \& Planning, 28(4), 385-402. https://doi.org/10.1108/02634501011053531.

Howard, D. R., \& Crompton, J. L. (1980). Financing, managing, and marketing recreation and park resources. USA: Financing, managing, and marketing recreation and park resources.

Howat, G., Absher, J., Crilley, G., \& Milne, I. (1996). Measuring customer service quality in sports and leisure centres. Managing Leisure, 1(2), 77-89. https://doi.org/10.1080/136067196376456

Hsu, C. H., Chang, T. M., Wang, S. Y., \& Lin, P. Y. (2007). Integrating Kano's model into quality function deployment to facilitate decision analysis for service quality. In Proceedings of the 8th WSEAS Internatinal Conference on Mathematics and Computers in Business and Economics (pp. 226-232).

Imamoğlu, A. F. (1998). Sport services in terms of understaning of total quality management. Journal of Physical Education and Sports Sciences, 3(2), 51-62. Retrieved from http://dergipark.gov.tr/gbesbd/issue/27956/305110

Kano, N., Seraku, N., Takahashi, F., \& Tsuji, S. (1984). Attractive quality vs. Must be quality. Journal of the Japanese Society for Quality Control, 14(2), 39-48. https://doi.org/10.20684/quality.14.2_147

Karasar, N. (2014). Scientific research method. 27. Edition. Ankara: Nobel Publishing.

Ko, Y. J., \& Pastore, D. L. (2005). A Hierarchial model of service quality for the recreational sport industry. Sport Marketing Quarterly, 14(2), 84-97.

https://www.researchgate.net/publication/285816752_A_hierarchical_model_of_service_quality_for_the_recreatio nal_sport_industry

Kuo, Y. F. (2004). Integrating Kano's model into web-community service quality. Total Quality Management \& Business Excellence, 15(7), 925-939. https://doi.org/10.1080/14783360410001681854

LaVoi, N. M. (2007). Physical activity behavior: What girls do. In M. J. Kane \& N. M. LaVoi (Eds.), The 2007 Tucker Center research report-Developing physically active girls: An evidencebased multidisciplinary approach (pp. 15). Minneapolis, MN: The Tucker Center for Research on Girls \& Women in Sport, University of Minnesota.

Öztürk, S. A. (1996). Enhancement of quality dimensions and quality in service enterprises. Journal of Productivity, 25(2), 65-80.

Papadimitriou, D. A., \& Karteliotis, K. (2000). The service quality expectations in private sport and fitness centers: A Re-examination of the factor structure. Sport Marketing Quarterly, 9(3), 158-164. https://www.researchgate.net/publication/288961707_The_service_quality_expectations_in_private_sport_and_fit ness_centers_A_reexamination_of_the_factor_structure.

Parasuraman, A., Zeithaml, V. A., \& Berry, L. L. (1985). A conceptual model of service quality and its implications for future research. the Journal of Marketing, 41-50. https://doi.org/10.2307/1251430

Parasuraman, A., Zeithaml, V. A., \& Berry, L. L. (1988). SERVQUAL: A multiple-item scale for measuring consumer perceptions of service quality. Journal of Retailing, 64(1), 12.

https://www.researchgate.net/publication/225083802_SERVQUAL_A_multiple-_Item_Scale_for_measuring_cons umer_perceptions_of_service_quality

Sahney, S. (2011). Delighting customers of management education in India: a student perspective, part I. The TQM Journal, 23(6), 644-658. https://doi.org/10.1108/17542731111157635

Silvestro, R. (2002). Dispelling the modern myth: Employee satisfaction and loyalty drive service profitability. International Journal of Operations \& Production Management, 22(1), 30-49. https://doi.org/10.1108/01443570210412060

Sofyalioglu, Ç., \& Tunail, I. (2012). Use of the Kano's model in the quality function deployment planning Matrix. Ege 
Academic Review, 12(1), 125-135. https://doi.org/10.21121/eab.2012119551

Taylor, P., \& Godfrey, A. (2003). Performance measurement in English local authority sports facilities. Public performance \& management review, 26(3), 251-262.

https://www.jstor.org/stable/3381286?seq=1\#page_scan_tab_contents

Theodorakis, N. D., Howat, G., Ko, Y. J., \& Avourdiadou, S. (2014). A comparison of service evaluation models in the context of sport and fitness centres in Greece. Managing Leisure, 19(1), 18-35. https://doi.org/10.1080/13606719.2013.849505.

Theodorakis, N., Kambitsis, C., \& Laios, A. (2001). Relationship between measures of service quality and satisfaction of spectators in professional sports. Managing Service Quality: An International Journal, 11(6), 431-438. https://doi.org/10.1108/09604520110410638

Tontini, G., \& Picolo, J. D. (2013). Identifying the impact of incremental innovations on customer satisfaction using a fusion method between importance-performance analysis and Kano model. International Journal of Quality \& Reliability Management, 31(1), 32-52. https://doi.org/10.1108/IJQRM-05-2012-0062

Uçan, Y. (2007). Developing the perceived service quality scale of sport-fitness centers. Doctorate Thesis. Abant İzzet Baysal University, Social Sciences Institute, Bolu, Turkey.

Üzüm, H., Yeşildağ, B., Karlı, Ü., Ünlü, H., Parlar, F. M., Çokpartal, C., \& Tekin, N. (2016). Investigation of service quality perceptions of public and private sport centre customers. Journal of Abant İzzet Baysal University Institute of Social Sciences, 16(3), 167-180. http://dx.doi.org/10.11616/AbantSbe

Xu, Q., Jiao, R. J., Yang, X., Helander, M., Khalid, H. M., \& Opperud, A. (2009). An analytical Kano model for customer need analysis. Design Studies, 30(1), 87-110. https://doi.org/10.1016/j.destud.2008.07.001.

Yerlisu Lapa, T., \& Baştaç, E. (2012). Evaluating the service quality assessment of individuals attending fitness centers in Antalya. Pamukkale Journal of Sport Sciences, 3(1), 42-52. http://psbd.pau.edu.tr/article/view/1062000077

Yıldız, K., Polat, E., Sönmezoğlu, U., \& Çokpartal, C. (2016). An analysis on the determinants of service quality perceived by members of the fitness center. Niğde University Journal of Physical Education And Sport Sciencesi, 10(3), 453-464. http://dergi.nigde.edu.tr/index.php/besyodergi/article/view/1393

Yıldiz, S. M. (2009). Sport and physical activity services: A Broad classification. Balikesir University Journal of Social Sciences $\quad$ Institute, $12(22), \quad 1-10$. http://sbe.balikesir.edu.tr/dergi/index.php?option=com_content\&task=view\&id=77\&Itemid=86

Yildiz, S. M. (2011). An importance-performance analysis of fitness center service quality: Empirical results from fitness centers in Turkey. African Journal of Business Management, 5(16), 7031-7041. https://doi.org/10.5897/AJBM11.674

Yıldız, S., Duyan, M., \& Günel, İ. (2018). The Effect of service quality on customer satisfaction: An Emprical study on fitnss centers' customers. Journal of Sport Sciences Researches, 3 (1), 1-8. Retrieved from http://dergipark.gov.tr/jssr/issue/33957/344971

Yildiz, Y. (2012). Investigation of the affect of the customer satisfaction on the customer loyalty in fitness centers. Selçuk University Journal of Physical Education and Sport Science, 14(2), 217-222.

Yıldız, Y., Onağ, Z., \& Onağ, A. O. (2013). Investigating of perceived service quality in sport and recreation services: A Sample of Fitness Center. International Refereed Journal of Humanities and Academic Sciences, 2(3), 114-130. https://doi.org/10.17368/UHBAB.201338830

Yu, H. S., Zhang, J. J., Kim, D. H., Chen, K. K., Henderson, C., Min, S. D., \& Huang, H. (2014). Service quality, perceived value, customer satisfaction, and behavioral intention among fitness center members aged 60 years and over. Social Behavior and Personality: An international journal, 42(5), 757-767. https://doi.org/10.2224/sbp.2014.42.5.757

Zeithaml, V. A., Parasuraman, A., \& Berry, L. L. (1985). Problems and strategies in services marketing. Journal of Marketing, 49(2), 33-46. https://doi.org/10.2307/1251563

\section{Copyrights}

Copyright for this article is retained by the author(s), with first publication rights granted to the journal.

This is an open-access article distributed under the terms and conditions of the Creative Commons Attribution license which permits unrestricted use, distribution, and reproduction in any medium, provided the original work is properly cited. 